\title{
Erosion of Malaysian Student Morals: A Survey of Private Schools
}

Nur Fiezila Mode Rezaly, Hishamuddine Ahmad and Nor Hasnida Che Md Ghazali

To Link this Article: http://dx.doi.org/10.6007/IJARBSS/v11-i2/8372

DOI:10.6007/IJARBSS/v11-i2/8372

Received: 10 December 2020, Revised: 03 January 2021, Accepted: 25 January 2021

Published Online: 10 February 2021

In-Text Citation: (Rezaly et al., 2021)

To Cite this Article: Rezaly, N. F. M., Ahmad, H., and Ghazali, N. H. C. M. (2021). Erosion of Malaysian Student Morals: A Survey of Private Schools. International Journal of Academic Research in Business and Social Sciences, 11(2), 141-150.

\section{Copyright: (c) 2021 The Author(s)}

Published by Human Resource Management Academic Research Society (www.hrmars.com) This article is published under the Creative Commons Attribution (CC BY 4.0) license. Anyone may reproduce, distribute, translate and create derivative works of this article (for both commercial and non-commercial purposes), subject to full attribution to the original publication and authors. The full terms of this license may be seen

at: http://creativecommons.org/licences/by/4.0/legalcode

Vol. 11, No. 2, 2021, Pg. 141 - 150

Full Terms \& Conditions of access and use can be found at http://hrmars.com/index.php/pages/detail/publication-ethics 


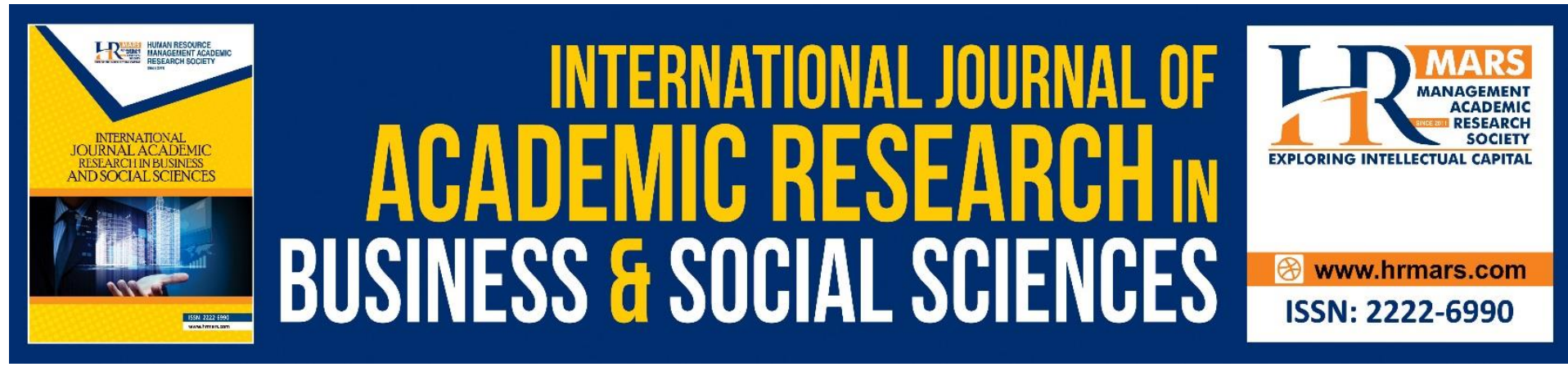

\title{
Erosion of Malaysian Student Morals: A Survey of Private Schools
}

\author{
Nur Fiezila Mode Rezaly, Hishamuddine Ahmad and Nor \\ Hasnida Che Md Ghazali \\ Faculty of Human Development, Universiti Pendidikan Sultan Idris, Malaysia
}

\begin{abstract}
Noble morals are the catalyst for the progress and perfection of life, but bad morals are effective destroyers and pests that destroy humanity and the height of human life. The relationship between morality and the downfall of a country should not be taken lightly. Without careful monitoring, the generation of the country's heirs will fall into reprehensible moral conduct that will inhibit the aspiration to drive all the aspirations of national development. In the process of teaching and learning in schools in order to achieve the national education mission, the curriculum is a concept of transformation from various levels passed by leaving impact on learners in the forms of models, ideas and actions held through activities conducted in educational institutions. This quantitative study aims to understand the morals of Malaysian students who get an education in private schools in the Klang Valley as the curriculum adopted is different from the national curriculum.
\end{abstract}

Keywords: Moral, Human Civilization, Student, Private School, Quantitative Study.

\section{Introduction}

The gift of civilization bestowed on a nation must be maintained. History also proves that the progress and excellence of a nation lie in the morals of its people. According to Man, Puji and Mohamad (2018), morality is an indicator or measure of the development of a nation's civilization. Scientists and philosophers also recognize the importance of morality in the construction of human dignity and human civilization. In general, all religions and beliefs have certain doctrines and practices in religion that need to be practiced by their followers. The doctrine is contained in the holy books of religions such as the Qur'an for Muslims, the Torah (Old Testament) for Jews, the Gospel (New Testament) for Christians and the Vedic books of Hindus. It is these doctrines and practices that guide human life to successfully create a variety of superior civilizations.

The word moral is derived from the Latin, "mores", which is the plural of the word "mos" which means custom (Sarinah, 2017). Ee (1988) defines morality as "individual behavior that coincides with ethics, manners, manners and rules of society". Hamid, Suratman and Othman (2001) statement that morality is a noble human behavior that is noble or has good manners. The description of these moral values is translated through the character, values, identity and behavior of individuals and society as a whole (Hamid, Balwi, Othman, \& Kassim, 2004). 
The Ministry of Education Malaysia (MOE) has made it compulsory for Islamic Education and Moral Education subjects to be taught in all schools in Malaysia to inculcate religious values and moral values in students (Ministry of Education, 2019). However, the question of whether the MOE's aspirations can be achieved or not depends on the extent to which the schools comply with this ruling. It is known that the curriculum practiced in the private schools that are abundant in Malaysia is very different from the curriculum adopted in full government aided schools. The increase in statistics involving student misconduct and discipline as reported by the mass media Bernama (2019) leads to a discussion on whether the school curriculum also has an impact on student morals.

\section{Literature Review \\ Development of Learning Theory}

To produce a generation with a good personality is the aspiration of every educational institution in this country to ensure the well-being of the nation and the country (Ministry of Education Malaysia, 2015). This responsibility must be borne with full commitment by all parties, whether students, educators, administrators, legislators and the government (Weber \& Bergan, 2005). In general, every education system needs to consider the learning aspects accepted by each student (National Academies of Sciences, Engineering and Medicine, 2018). In this regard, various theories need to be refined to produce an education system that meets the goals of national education policy (Viennet \& Pont, 2017). According to Chowdhury (2016), in discussing the desired educational product that is students who have pure moral values who are able to contribute to the country and the nation, we first need to talk about how a person achieves the lessons that are conveyed to them.

Therefore, Schunk (2012) stated that, we need to know the learning approaches introduced by educational scholars such as cognitive learning, behaviorist, constructivist, humanist and even social. These learning theories need to be assimilated into the study to cultivate and create a learning method that meets the aspirations of every student, parent, teacher, school administrator and even the country (Yahaya \& Razak, 2018). Aziz (2019) highlighted that producing a holistic generation requires an approach that not only generates academic excellence, but also has a sustainable personality in bringing Malaysia into a bright future, developed and united people.

\section{Thinking Approach}

Discussions on learning theory will not be complete without discussing aspects of thinking (Lumen Learning, 2020). This is because every human being is endowed with a mind to think. Through the process of thinking, information and knowledge come. Thinking also makes an individual know about something and makes the individual experience (Rahimi, 2015). According to Zakaria (2018), Thinking Skills (TS) is an intellectual process that involves conceptualization, application, analysis, syntax and evaluation of information collected or produced through observation, experience, reflection, thinking or communication as the basis for an action. Thus, the thought process involves the interaction between knowledge, cognitive skills and attitudes or values (Gek, 2017). (Refer to Figure 1.0) 


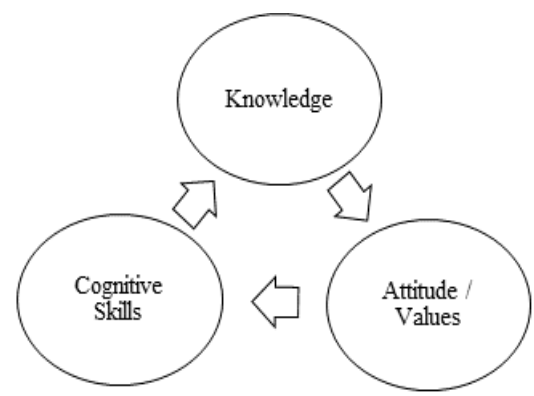

Figure 1.0 Ministry of Education Malaysia Thinking Process Model

The Ministry of Education Malaysia (2001) formulates the Thinking Skills Model contains elements of critical and creative thinking skills. Hamat, et al. (2008) stated that critical thinking skills are the ability to evaluate the validity of an idea and be evaluative in nature. During critical thinking, there is an exploration of thought to evaluate an idea logically and rationally to make sound judgments using reasonable reasons and evidence (Ministry of Education, 2016). While creative thinking skills are the ability to digest and generate original and generic ideas (Sharp, 2004). It is through creative thinking that new ideas are generated through inspiration or a combination of existing ideas. Innovation of new, unique, useful and quality materials, activities and projects will result in the product of creative thinking (Ministry of Education, 2016). Through the development of this learning process as well as thinking skills, an existing curriculum in private schools should be re-evaluated or need to be improved to produce individuals who master high-level thinking skills, problem-solving skills, communication skills and most importantly soft skills to succeed in the field ventured into the 21st century (Ismail, 2019).

\section{Problems of Student Morality Study in Private Schools}

The curriculum practiced in schools is outlined by the MOE. The basic skills of $3 \mathrm{M}$ (reading, writing and counting) have now been improved with the launch Industrial Revolution 4.0 where the application of humanity, i.e. Humanizing students, shaping the personality of students through the Malaysian education system with the application of values as a whole need to be done to address competition with artificial intelligence which will dominate the job market (Ismail, 2019).

Based on this understanding, the Ministry of Education has structured all the curriculum in line with the goal of producing holistic students as projected by progressive education pioneers such as Francis Parker, John Dewey, Maria Montessori and Rudolf Steiner (New Straits Times, 2016). To achieve this, school administrators need to emphasize the moral, emotional, physical, psychological and spiritual dimensions of students (Chowdhury, 2016). However, the existence of private schools with the use of different curricula, has raised the question of whether the aspirations of the Ministry of Education can be achieved or not. This is because in private schools there is clearly less attention and emphasis on good moral development (Rahman, 2013).

Rahman (2013) also highlighted that moral decay may occur as the education system in private schools is more focused on academic achievement than on good character formation. This concern is well-founded where the number of Malaysian students currently attending private schools has increased from year to year. A total of 208,043 students was recorded in 2017 compared to 175,713 in 2013, an increase of 18 percent in less than 5 years 
shows that more and more parents choose a different curriculum from the curriculum developed by the MOE (Ministry of Education, 2019).

In fact, the lack of appreciation of moral knowledge as outlined by the MOE will lead to the spread of the problem of student misconduct which is becoming more and more serious year after year. (Rashid, Hamid, \& Bakar, 2015). Based on this statement, in the Student Disciplinary Misconduct System (SSDM) by the MOE has exceeded 50 types of normal offenses listed, including dishonest or deceptive behavior, obscene behavior, rude behavior, destructive behavior and criminal behavior (Mohammad \& Zin, 2006). Lack of appreciation and practice of noble values has triggered the issue of moral decay until today where the involvement of students today in various types of misconduct not only in light activities but even student misconduct has led to extreme crimes such as drug abuse, harassment, hanging out, stealing, smoking, sexual misconduct, murder, joining gangs and militants are among the reported (Haridi, 2016; Perpustakaan Laman Hikmah, 2019; Polis Diraja Malaysia, 2019). According to statistics in 2018, crimes involving school students recorded by the Royal Malaysian Police (PDRM) were 1,722 cases in 2017 while a total of 1,285 cases was recorded in 2018 (Issahak, 2019). Therefore, it is very important for researchers to take the initiative to conduct a study to see the extent to which the curriculum in private schools influences the moral practices of Malaysian students.

\section{Methodology}

Raman (2009) states methodology is a systematic procedure in combining research approaches and data analysis to ensure that research performance can be achieved well. Each selection of this methodology is important because it ensures that good data collection methods are carried out according to the research questions and objectives (Goundar, 2012). Creswell J. W. (2009) explained the choice of methodology can also affect the quality of research.

This study will use quantitative methods to confirm the hypothesis as this method has been found to be able to provide statistical evidence in supporting the hypothesis (Hennessy \& Patterson, 2012; Johnson \& Christensen, 2010; McNeil, Frey, \& Embrechts, 2010; Punch, 2013). It is through this quantitative method that validity and reliability can be demonstrated by constructs (Pinsonneault \& Kraemer, 1993). Quantitative research is a form of study that uses statistics and is numerical in nature with measurable parameters that aim to identify the relationship between the curriculum in private schools on the morals of Malaysian students.

The survey method is one of the most popular non-experimental research methods used in various fields, especially in the social sciences. According to Ishak, Abdullah and Ishak (2019) since the method of study is simple and can be done on things that are happening (Snyder, 2019). The survey method is a way of gathering information that can explain the nature of various data including aspects of views and attitudes (Lau \& Kuziemsky, 2017). The information obtained can be used to affirm the true state of a matter related to a community in its own context, then can be used to answer the questions posed at the beginning of a study. In addition, survey methods can unravel the questions of "what" and "why" about a problem (Darusalam \& Hussin, 2016).

This study will use the method of closed-ended survey questions as it is able to explain the relationship between the constructs that have been identified (Hua, 2016). The data collected through the survey question method is in the form of numbers, unchanged and detailed which is the focus of quantitative research (Babbie, 2013; Labaree, 2015). Typically, the types of survey questions in quantitative studies will fall into the form of "quantity or 
information, category, list or multiple choice, scale, ranking, complex grid or table, and closed" (Mukherji \& Albon, 2010; Zohrabi, 2013). This study will use scalable closed-ended research questions to enable researchers to avoid any doubts about the response or feedback (Yusuff, 2017).

\section{Population and Sample Size}

Sample size is closely related to the effectiveness of a study (Hua, 2016). The sample selected should represent the entire population (Jha, 2017). In other words, the information obtained from the selected sample should be as close as possible to the information to be obtained from the population. A large number of samples will actually represent the target population (Agresti \& Finlay, 2009). To conduct this study, there are a total of 458 private schools in Malaysia (Ministry of Education Malaysia, 2017) and according to the Private Education Division, Ministry of Education Malaysia (2017), the number of Malaysian students currently receiving an education in private schools is 142,347 students.

\section{Data Analysis}

This study will use SPSS to analyze data because the SPSS software is user friendly and capable of doing whatever we need in analyzing data (Muijs, 2004). Furthermore, SPSS can be found in most high-end institutions and it is a Windows-based program which means it shares many features with other Windows-based software (Arkkelin, 2014). This study will use descriptive analysis and inference analysis. Descriptive analysis was used to identify the influence on student morale as a result of the curriculum practiced and to describe the background of the respondents. Meanwhile, inference analysis was used to answer the hypotheses put forward by the study involving validation factor analysis (CFA) and structural equation analysis (SEM). Next, regression analysis will be performed to determine the relationship between the variables. The next analysis is the Cronbach's Alpha Analysis which aims to measure internal consistency or reliability. Finally, an Independence test will be performed to determine whether there is a relationship between the constructs studied.

\section{Conclusion}

This study will enable the Ministry of Education to make a reference to the effects that will be experienced by the country with the increase in the number of Malaysian students in private schools as we are talking about today. Therefore, appropriate measures can be taken to overcome the weaknesses if they exist. The aspiration of the country to produce superior human capital and noble character can be achieved by the creation of students, especially students in private schools who are virtuous and have a healthy mind. This is because a good heart and mind will reflect one's politeness and wisdom in thoughts and actions.

Through this study, the researcher will be able to suggest that officers from the Ministry of Education to make regular inspections from time to time and continue to review the practice of applying the noble moral values applied in schools not supervised by MOE. It must be in line with the National Education Policy, requires proper review and implement the best Education Development Plan in the private school curriculum system in Malaysia for the formation of holistic Malaysian students who not only excel academically but also have admirable moral values towards themselves, family, peers, community and country.

Consequently, this study hopes to contribute to the knowledge of the possible mechanism for achieving the perfection of an individual's life from a moral point of view (Hilmi, 2004; Sulaiman, 2014). The perspective expressed by Omar (2010) who states that a 
person's morals or psychic disposition is dynamic and flexible where it is in response to stimuli obtained from education, rules, law and discipline. Based on this understanding, this study is designed to unravel the question of the level of morality of Malaysian students receiving formal education in private schools around the Klang Valley by focusing on building a moral model that will be empirically tested through a structural equation capitalization approach.

\section{References}

Agresti, A., \& Finlay, B. (2009). Statistical Methods for the Social Sciences, 4th Edition. New Jersey: Pearson Education Inc.

Arkkelin, D. (2014). Using SPSS to Understand Research and Data Analysis. Indiana: Valparaiso University.

Aziz, A. R. (2019). Pupuk Inovasi Lahir Graduan Holistik. Retrieved from BH Online: https://www.bharian.com.my/kolumnis/2019/05/567789/pupuk-inovasi-lahirgraduan-holistik

Babbie, E. (2013). The Practice of Social Research, Thirteenth Edition. Belmont, CA: Cengage Learning.

Bernama. (2019). KPN : Pelajar berjinak-jinak dalam jenayah ekstrem.

Chowdhury, M. (2016). Emphasizing Morals, Values, Ethics, And Character Education In Science Education And Science Teaching. The Malaysian Online Journal of Educational Science, 4(2), 1-16.

Creswell, J. W. (2009). Research Design: Qualitative, Quantitative, and Mixed Methods Approaches. 3rd Edition. Los Angeles: Sage Publications Inc.

Darusalam, G., \& Hussin, S. (2016). Methodologi Penyelidikan Dalam pendidikan: Amalan dan Analisis Kajian. Kuala Lumpur: Universiti Malaya.

Ee, A. (1988). Pendidikan Moral untuk Bakal Guru. Petaling Jaya: Longman Malaysia.

Gek, C. B. (2017). Pengetahuan dan Pengaplikasian Kemahiran Berfikir Asas Tinggi dalam Kalangan Guru Teknik dan Vokasional. Master Thesis. Parit Raja, Johor, Malaysia: Fakulti Pendidikan Teknikal dan Vokasional, Universiti Tun Hussein Onn Malaysia.

Goundar, S. (2012). Chapter 3 - Research Methodology and Research Method. In S. Goundar, Cloud Computing. https://www.researchgate.net.

Hamat, M. F., Abdullah, W. S., Seman, A. C., Kasim, T. S., Rahman, S. M., Latif, F. A., \& Husin, F. C. (2008). Penerapan Pemikiran Kritis Menerusi Silibus Pendidikan Islam Kurikulum Bersepadu Sekolah Menengah (KBSM): Kajian di SMKA Negeri Melaka. Penyelidikan Fundamental Universiti Malaya (FF017/2005D).

Hamid, M. A., Balwi, M. K., Othman, M. F., \& Kassim, O. A. (2004). Wajah Moral Masyarakat Melayu Pascamoden: Antara Realiti, Harapan dan Gagasan Pendidikan Moral Tinggi. Skudai: Universiti Teknologi Malaysia.

Hamid, M. A., Suratman, A. S., \& Othman, M. F. (2001). Senario Pendidikan Moral Masyarakat Melayu Zaman Teknologi Komunikasi Maklumat (ICT): Trend, Hala Tuju Dan Model Pendidikan Moral Keluarga Islam. Jurnal Teknologi E (35E), 45-70.

Haridi, N. H. (2016). Program Agama di Pusat Pemulihan Akhlak Jabatan Kebajikan Masyarakat (JKM): Kajian dari Aspek Pelaksanaan dan Keberkesanan. PhD Thesis. Kuala Lumpur, Malaysia: Universiti Malaya.

Hennessy, J., \& Patterson, D. (2012). Computer Architecture : A Quantitative Approach. Elsevier.

Hilmi, M. (2004). Al-Akhlaq Bayna Al-Falasifah Wa-'Ulama' Al-Islam. Bairut, Dar: Bayrut : Dar Al-Kutub Al-'Ilmiyyah. 
Hua, A. K. (2016). Pengenalan Rangkakerja Metodologi dalam Kajian Penyelidikan: Satu Kajian Kes. Malaysian Journal of Social Sciences and Humanities, 1(1), 17-23.

Hua, A. K. (2016). Pengenalan Rangkakerja Metodologi dalam Kajian Penyelidikan: Satu Kajian Komprehensif. Malaysian Journal of Social Sciences and Humanities, 4(4), 42-52.

Ishak, F. H., Abdullah, M. Y., \& Ishak, S. H. (2019). Hubungan Pelaksaan Pembelajaran Masteri dan Penguasaan Konsep Sains dengan Pencapaian Mata Pelajaran Sains Sekolah Rendah di Melaka. Jurnal Kesidang, 63-76.

Ismail, H. (2019). https://www.pendidik.com.my/. Retrieved from https://www.pendidik.com.my/2019/01/30/amanat-dr-maszleetiga-aspirasikementerian-pendidikan-2018-2023-bakal-kembalikan-kegemilangan-pendidikannegara/

Issahak, M. A. (2019). Jenayah dalam kalangan pelajar masih membimbangkan. Kuala Lumpur: BH Online.

Jha, G. (2017). What Is Survey Sampling? Retrieved from 6 Sampling Techniques: How to Choose a Representative Subset of the Population: https://humansofdata.atlan.com/2017/07/6-sampling-techniques-chooserepresentative-subset/

Johnson, R., \& Christensen, L. B. (2010). Educational Research: Quantitative, Qualitative and Mixed Approaches. Sage Publications.

Labaree, R. V. (2015). Organizing Your Social Sciences Research Paper: Quantitative Methods. Retrieved from https://libguides.usc.edu: http://libguides.usc.edu/writingguide

Lau, F., \& Kuziemsky, C. (2017). Handbook of eHealth Evaluation: An Evidence-based Approach. Victoria (BC): University of Victoria.

Lumen Learning. (2020). Module 2: The Learning Process. Retrieved from Educational Psychology:

https://courses.lumenlearning.com/educationalpsychology/chapter/major-theoriesand-models-of-learning/

Man, N. D., Puji, T. I., \& Mohamad, S. (2018). Menangani Keruntuhan Akhlak Masa Kini Menurut Islam. Jurnal al-Turath, 3 (1), 55-63.

McNeil, A. J., Frey, R., \& Embrechts, P. (2010). Quantitative Risk Management: Concepts, Techniques and Tools. New Jersey, United States: Princeton University Press.

Ministry of Education. (2016). Huraian Sukatan Pelajaran Bahasa Melayu Sekolah Menengah Tingkatan Empat. Putrajaya: Kementerian Pendidikan Malaysia.

Ministry of Education. (2019). Portal Rasmi Kementerian Pendidikan Malaysia. Retrieved from www.moe.gov.my

Ministry of Education Malaysia. (2001). Kemahiran Berfikir Dalam Pengajaran dan Pembelajaran. Putrajaya: Pusat Perkembangan Kurikulum, Kementerian Pendidikan Malaysia.

Ministry of Education Malaysia. (2015). Malaysia Education Blueprint 2015 - 2025. Putrajaya: Ministry of Education Malaysia.

Ministry of Education Malaysia. (2017). Perangkaan Pendidikan Malaysia. Putrajaya: Ministry of Education Malaysia.

Mohammad, A., \& Zin, A. A. (2006). Ilmu dan Pembangunan Masyarakat Islam", dalam . Siri Teks Pengajian Tinggi. In S. T. Tinggi, Tamadun Islam dan Tamadun Melayu. Kuala Lumpur: Penerbit Universiti Malaya.

Muijs, D. D. (2004). Doing Quantitative Research in Education: with SPSS. City Road, London: Sage Publications Ltd. 
Mukherji, P., \& Albon, D. (2010). Research Methods in Early Childhood: An Introductory Guide. City Road, London: Sage Publications Inc.

National Academies of Sciences, Engineering and Medicine. (2018). How People Learn II: Learners, Contexts and Cultures. Washington DC: The National Academies Press.

New Straits Times. (2016). Strive for wider, wholesome learning. Retrieved from https://www.nst.com.my: https://www.nst.com.my/news/2016/10/179485/strivewider-wholesome-learning

Omar, M. N. (2010). Falsafah Akhlak. Bangi, Selangor: Universiti Kebangsaan Malaysia.

Perpustakaan Laman Hikmah. (2019, June). Gejala Sosial. Melaka, Malaysia: Universiti Teknikal Malaysia Melaka.

Pinsonneault, A., \& Kraemer, K. (1993). Survey research methodology in management information system: an assessment. Journal of Management Information System, 10, 75-105.

Polis Diraja Malaysia. (2019, February 8). Perutusan Sempenan Program Jom Ke Sekolah Peringkat Kebangsaan Tahun 2019. Kuala Lumpur, Malaysia: Polis Diraja Malaysia.

Punch, K. F. (2013). Introduction to Social Research: Quantitative and Qualitative Approaches. Sage Publication.

Rahimi, N. H. (2015). Hubungan kesedaran metakognitif, penglibatan pembelajaran dan gaya pembelajaran terhadap tahap pemikiran reflektif pelajar pendidikan teknikal dan vokasional. Masters, Thesis. Universiti Putra Malaysia.

Rahman, S. A. (2013). Faktor Sosial dalam Pembentukan Akhlak Pelajar Sekolah Menengah. Seminar Pertama Pendidikan dan Penyelidikan Islam (pp. 478-492). Universiti Teknologi Malaysia.

Raman, M. U. (2009). Perbandingan Pencapaian Pembelajaran Bahasa Tamil Di Dalam Kelas Biasa dan Kelas POL. Masters Thesis. Kuala Lumpur, Wilayah Persekutuan: University of Malaya.

Rashid, A. M., Hamid, N. A., \& Bakar, N. H. (2015). Krisis Akhlak: Penguatkuasaan UndangUndang Sebagai Benteng Menanganinya. E-Journal Penyelidikan dan Inovasi, 2(1), 18.

Sarinah. (2017). Pendidikan Agama Islam. Yogyakarta: Deepublish.

Schunk, D. H. (2012). Learning Theories An Educational Perspective; Sixth Edition. Boston, MA: Pearson Education, Inc.

Sharp, C. (2004). Developing young children's creativity: what can we learn from research? Autum, 32, 5-12.

Snyder, H. (2019). Literature review as a research methodology: An overview and guidelines. Journal of Business Research, 104, 333-339.

Sulaiman, A. M. (2014). Peranan Guru Pendidikan Islam Dalam Pembentukan Akhlak Murid Dari Aspek Hubungan Guru-Murid Berasaskan Abu Talib Al-Makki. PhD thesis. University of Malaya.

Viennet, R., \& Pont, B. (2017). Education Policy Implementation: A Literature Review and Proposed Framework. Directorate for Education and Skills.

Weber, L., \& Bergan, S. (2005). The public responsibility for higher education and research. Strasbourg Cedex: Council of Europe Publishing.

Yahaya, A., \& Razak, S. A. (2018). Hubungan Antara Gaya Pembelajaran dan Kaedah Pengajaran Dengan Pencapaian Mata Pelajaran Pengajian Kejuruteraan Awam Di Sekolah Menengah Teknik Di Negeri Sembilan. Universiti Teknologi Malaysia Institutional Repository. Skudai, Johor, Malaysia: Fakulti Pendidikan . 
Yusuff, A. S. (2017). Campuran Pemasaran dan Ekuiti Jenama Halal Keseluruhan. DBA Thesis. Sintok, Kedah, Malaysia: Universiti Utara Malaysia.

Zakaria, S. (2018). Penerapan Kemahiran Berfikir Aras Tinggi (Kbat) Dalam Soalan Kertas Dua Tasawwur Islam Spm : Satu Analisis. Prosiding Seminar Kebangsaan Majlis Dekan Pendidikan Universiti Awam. Universiti Sultan Zainal Abidin.

Zohrabi, M. (2013). Mixed Method Research: Instruments, Validity, Reliability and Reporting Findings. Theory and Practice in Language Studies, 3(2), 254-262. 